\title{
Sense of meaning in life as a factor protecting middle school adolescents from perpetrating and experiencing peer violence
}

\author{
Poczucie sensu życia jako czynnik chroniący młodzież gimnazjalną \\ przed stosowaniem i doznawaniem przemocy rówieśniczej
}

\author{
'Department of Clinical Psychology of Children and Adolescents, Institute of Psychology, Maria Grzegorzewska University, Warsaw, Poland \\ ${ }^{2}$ Department of Child and Adolescent Health, Institute of Mother and Child, Warsaw, Poland \\ Correspondence: Dorota Zawadzka, Department of Clinical Psychology of Children and Adolescents, Institute of Psychology, Maria Grzegorzewska University, Szczęśliwicka 40, 02-353 Warsaw; \\ Department of Child and Adolescent Health, Institute of Mother and Child, Kasprzaka 17a, 01-211 Warsaw, Poland, e-mail: dzawadzka@aps.edu.pl, dorzawadzka@imid.med.pl
}

\author{
'Zakład Psychologii Klinicznej Dzieci i Młodzieży, Instytut Psychologii, Akademia Pedagogiki Specjalnej im. Marii Grzegorzewskiej, Warszawa, Polska \\ 2 Zakład Zdrowia Dzieci i Młodzieży, Instytut Matki i Dziecka, Warszawa, Polska \\ Adres do korespondencji: Dorota Zawadzka, Zakład Psychologii Klinicznej Dzieci i Młodzieży, Instytut Psychologii, Akademia Pedagogiki Specjalnej im. Marii Grzegorzewskiej, \\ ul. Szzzę́liwicka 40, 02-353 Warszawa; Zakład Zdrowia Dzieci i Młodzieży, Instytut Matki i Dziecka, ul. Kasprzaka 17a, 01-211 Warszawa, e-mail: dzawadzka@aps.edu.pl, dorzawadzka@imid.med.pl
}

\begin{abstract}
Background and aims: Searching for the meaning of life is the basic motivation in human life, and lacking a sense of meaningfulness can lead to a range of disorders such as assuming the roles of victim and perpetrator of peer violence. Methods: This questionnaire-based study involved a total of 4,085 pupils (52\% girls) from 70 middle schools located in all Polish voivodeships. The study used an abbreviated univariate version of the Purpose in Life Test scale, while two questions about peer violence were derived from the Polish version of the research protocol employed in the international study Health Behaviour in School-aged Children (HBSC). Both univariate and multivariate analyses - including logistic regression - were performed. Results: Out of 4,085 middle school pupils $26.8 \%$ were perpetrators and $29.8 \%$ were victims of peer violence at least once during the preceding 2 months. Boys were found to be both perpetrators and victims significantly more frequently than girls. Grade 3 pupils experienced violence from their peers significantly less frequently than grade 1 and grade 2 pupils. Regression analysis showed a significantly lower probability of being a victim or perpetrator of peer violence (at least 1-2 times during the 2 months preceding the questionnaire) in adolescents with a high sense of meaning in life. It was also found that girls were significantly less likely than boys to take on the roles of victims or perpetrators. The risk of being a victim of violence is also significantly decreased in middle school grade 3 pupils compared to grade 1 pupils. Conclusions: The potential practical implications of the analyses include the implementation of programmes aimed at highlighting universal and non-material values on which young people could rely. Based on the results of the study, it can be claimed that a high level of meaning in life is a factor protecting middle school adolescents from taking on the roles of both the victim and perpetrator of peer violence.
\end{abstract}

Keywords: sense of meaning in life, peer violence, middle school adolescents

Streszczenie Tło i cele: Poszukiwanie sensu życia jest podstawową motywacją w życiu człowieka, a jego brak może prowadzić do wielu zaburzeń, m.in. do wchodzenia w rolę zarówno ofiary, jak i sprawcy przemocy rówieśniczej. Metody: Anonimowym badaniem ankietowym objęto 4085 uczniów z 70 gimnazjów zlokalizowanych we wszystkich województwach w Polsce (52\% dziewczęta). W badaniu została użyta skrócona, jednoczynnikowa wersja skali Purpose in Life Test, natomiast dwa pytania dotyczące przemocy rówieśniczej zaczerpnięto z polskiej wersji protokołu badawczego pochodzącego z międzynarodowych badań Health Behaviour in School-aged Children (HBSC). Zastosowano analizy jednowymiarowe oraz wielowymiarowe, w tym regresję logistyczną. Wyniki: Spośród 4085 gimnazjalistów w ciągu ostatnich 2 miesięcy co najmniej raz 26,8\% było sprawcą, a 29,8\% padło ofiarą przemocy rówieśniczej. Chłopcy istotnie częściej niż dziewczęta znaleźli się w gronie zarówno sprawców, jak i ofiar przemocy rówieśniczej. Uczniowie klasy III istotnie rzadziej doznawali przemocy ze strony rówieśników w porównaniu z uczniami klas I oraz II. Analiza regresji wykazała u młodzieży z wysokim poczuciem sensu życia istotnie mniejsze prawdopodobieństwo zostania ofiarą lub sprawcą przemocy rówieśniczej (co najmniej 1-2 razy w ciągu ostatnich 2 miesięcy przed badaniem ankietowym). Stwierdzono też, że dziewczęta istotnie rzadziej wchodziły w rolę ofiary lub 
sprawcy niż chłopcy. Ryzyko bycia ofiarą przemocy istotnie zmniejsza również uczęszczanie do klasy III gimnazjum w porównaniu z uczniami klasy I. Wnioski: Implikacjami praktycznymi przeprowadzonych analiz może być wdrażanie programów kładących nacisk na eksponowanie wartości uniwersalnych i niematerialnych, do których młodzież mogłaby się odwoływać. Biorąc pod uwagę uzyskane rezultaty, można stwierdzić, że wysoki poziom sensu życia jest czynnikiem chroniącym młodzież gimnazjalną przed wchodzeniem w role zarówno ofiary, jak i sprawcy przemocy rówieśniczej.

Słowa kluczowe: poczucie sensu życia, przemoc rówieśnicza, młodzież gimnazjalna

\section{INTRODUCTION}

A ccording to the concept proposed by Viktor Frankl (1953) "man in every moment of his life can feel the need to take the trouble of finding and fulfilling his life with meaning." Based on a review of evidence from several scientific papers, Baumeister (1991) concluded that the pursuit of the sense of meaning in life can be explored and understood by referring to four main aspects. People who have satisfied all four of these needs are likely to regard their lives as meaningful. In contrast, people who are unable to satisfy one or more of them, tend to see their life as insufficiently meaningful. The four needs include:

1. Purpose. The essence of the need for purpose is the sense of causal connection between current actions and future outcomes. Future events give direction to the present which is interpreted as leading toward certain desirable goals. Two types of purpose can be identified. The first type comprises ends in themselves, i.e. goals focused on achieving the desired but not yet attained outcome or state. In this context, actions taken by a person are meaningful as a means of changing the current situation into a desirable future situation. The other is fulfilment, the category being subjective rather than objective. Life can be oriented toward a future anticipated state such as living happily ever after, finding reciprocated love or salvation (eternal life in paradise).

2. Values. Values can refer to moral issues, a sense of goodness or positive attitude to life, or justify certain courses of action. Values held by individuals help them decide whether certain actions are right or wrong. By acting consciously, people can feel secure thanks to their values: they believe that they have done the right things and hence minimise guilt, anxiety, regret or other forms of moral distress (Baumeister and Vohs, 2002). In his insightful discussion on the meaning of life, Frankl (1959/1976) identified values as the main indicator of meaningfulness. Values are hierarchical, and each question about whether something is good or bad typically requires moving to a higher level of abstraction and determinants of what can be recognised as right. Naturally, some things are good in themselves, and need no further justification. They can be referred to as value bases (Baumeister, 1991). For example, many people regard God's will as a foundation of the moral system. They recognize God's will as supremely right and good,

\section{WPROWADZENIE}

$\mathrm{K}$ oncepcja Viktora Frankla (1953) zakłada, że „człowiek w każdym momencie swojego życia może zuć potrzebę podjęcia trudu, którym jest odnalezienie oraz wypełnienie swojego życia sensem". Po przejrzeniu dowodów z kilku prac naukowych Baumeister (1991) stwierdził, że $\mathrm{w}$ analizie powodów poszukiwania i zrozumienia przez człowieka sensu egzystencji wyróżnić można cztery główne aspekty takiego działania. Ludzie, którzy zaspokoili cztery potrzeby wpływające na taką motywację, uważają swoje życie za pełne znaczenia. $\mathrm{Z}$ kolei jednostki, które nie mogą zaspokoić co najmniej jednej z nich, prawdopodobnie oceniają swoje życie za niewystarczająco istotne. Potrzebami tymi są:

1. Poczucie celowości. Jego esencją jest potrzeba odczuwania związku obecnych działań z przyszłymi wydarzeniami. Owe przyszłe wydarzenia nadają kierunek teraźniejszości, a ona postrzegana jest jako prowadząca ku obranym celom. Te z kolei można podzielić na dwa główne typy. Jednym jest cel sam w sobie - ma on za zadanie osiągnięcie pożądanego, ale jeszcze niezrealizowanego wyniku lub stanu. Działania danej osoby mają więc znaczenie jako sposób na przekształcenie obecnej sytuacji w pożądaną (przyszłą). Drugi typ to spełnienie - i jest to kategoria raczej subiektywna niż obiektywna. Życie może być ukierunkowane na niektóre przewidywane stany przyszłego spełnienia, takie jak życie długie i szczęśliwe, zakochanie się ze wzajemnością lub zbawienie (życie wieczne w raju).

2. Poczucie wartości. Może ono sprowadzać się do kwestii moralnych, oznaczać poczucie dobroci lub pozytywnego nastawienia do życia albo uzasadniać określone kierunki działania. To wyznawane wartości pomagają ludziom decydować, czy pewne czyny są właściwe, czy też nie. Działając świadomie, ludzie mogą czuć się bezpieczni właśnie dzięki wartościom - wierzą, że postąpili właściwie, i minimalizują w ten sposób poczucie winy, obawy, żal bądź inne formy niepokoju moralnego (Baumeister i Vohs, 2002). Frankl (1959/1976) w swoich bardzo istotnych rozważaniach nad sensem życia wskazał na wartości jako główny jego wyznacznik. Są one zhierarchizowane i każde pytanie o to, czy coś jest dobre, czy złe, odwołuje się zazwyczaj do wyższego poziomu abstrakcji i wyznaczników tego, co można uznać za słuszne. Pewne rzeczy są dobre same w sobie - nie trzeba dla nich szukać dalszego uzasadnienia. Można je nazwać wartościami bazowymi (Baumeister, 1991). Przykładowo dla wielu osób 
without holding that the existence of God also serves some higher purpose.

3. Efficacy. Efficacy essentially involves the belief that one's life can make a difference. Existence based on goals and values - but without a sense of efficacy - would be tragic, as people would know the desirable state without being able to put this knowledge to any use. It is relatively clear that everyone wants to have control over their environment and, at the same time, over themselves (Baumeister, 1998). A deep lack of control can lead to a serious personal crisis with a potential negative impact on both physical and mental health.

4. Self-worth. The majority of people tend to seek validation for the belief that they are good and worthy individuals. Self-worth can be pursued individually, for example by attempts to establish themselves as superior to others (Wood, 1989), but also collectively, when people build their sense of self-worth from belonging to a group or category of people whom they regard as worthy (Turner, 1975).

It is commonly believed that there exists a single source that will satisfy all human needs for meaning. Indeed, the colloquial question about the sense of existence is usually formulated as if there is only one answer: "What is the meaning of life?". The reality, however, seems to be more complicated, with people usually deriving a sense of meaningfulness from multiple sources including values such as family, love, work, religion and a variety of personal projects (Emmons, 1997). In this way, they protect themselves from a situation where they never find it at all. Dissatisfaction with one's personal life, divorce or family breakdown can be compensated, for example, by a successful career or religious comfort. The fact that there are multiple sources of sense is also beneficial in that each sphere separately involves fewer risks, which translates into a greater possibility of satisfying all four needs. For example, one's professional career may offer many goals and provide a strong sense of efficacy but, at the same time, carry little significance from the perspective of held values. A person may believe that their career is interesting and rewarding, however, it fails to yield them a powerful sense of what is right and that is wrong. At the same time, the sense of value and balance can be derived from a rich and satisfying family life (being guided by the well-being of children is widely regarded as the right choice).

In adolescents, mental health is strongly associated with the sense of meaningfulness in life (Brassai et al., 2011). Seeking the meaning of life represents a basic human motivation, and lacking a sense of meaning can lead to a range of disorders such as assuming the roles of victim or perpetrator of peer violence. Bullying among pupils is a problem that has plagued schools for a very long time. The fact that some children are frequently and systematically harassed and attacked by other children has been addressed in a number of publications. Also, many adults admit to having been victims of bullying during their school years. wola Boża jest podstawą systemu moralnego. Uważają ją za absolutnie słuszną i dobrą - nie utrzymując, że istnienie Boga służy jeszcze innym, wyższym celom.

3. Poczucie skuteczności. Sprowadza się do przekonania, że w życiu można coś zmienić. Egzystencja oparta na celach i wartościach, ale bez jednoczesnego poczucia skuteczności byłaby tragiczna - wiedzielibyśmy bowiem, jaki stan jest pożądany, ale nie moglibyśmy nic z tą wiedzą zrobić. Jest względnie jasne, że każdy dąży do posiadania kontroli nad swoim otoczeniem i jednocześnie nad samym sobą (Baumeister, 1998). Jej głęboko odczuwany brak może sprowokować poważny kryzys osobisty, który ma potencjalnie negatywny wpływ na zdrowie fizyczne i psychiczne.

4. Poczucie własnej wartości. Większość ludzi szuka powodów, by wierzyć, że są osobami dobrymi, godnymi. Potrzebę tę można realizować indywidualnie, np. próbując wyróżnić się wśród innych (Wood, 1989), ale też w większym gronie - gdy poczucie własnej wartości uzależnia się od przynależności do jakiejś grupy lub kategorii ludzi, których uważa się za godnych (Turner, 1975).

Powszechnie sądzi się, że istnieje źródło, które zaspokoi wszystkie potrzeby sensu. Istotnie, potoczne pytanie o znaczenie egzystencji zwykle formułuje się tak, jakby odpowiedź była tylko jedna: „Jaki jest sens życia?”. Rzeczywistość wydaje się jednak bardziej skomplikowana, zazwyczaj bowiem ludzie czerpią poczucie sensu z wielu źródeł, odwołując się m.in. do takich wartości, jak rodzina, miłość, praca, religia i różne osobiste projekty (Emmons, 1997). W ten sposób bronią się przed sytuacją, w której nie mogliby go w ogóle odnaleźć. Niesatysfakcjonujące życie osobiste, rozwód czy rozpad rodziny mogą być rekompensowane np. zadowoleniem z pracy czy kwestiami religijnymi. Istnienie wielu źródeł sensu ma też i tę zaletę, że każdej sferze z oddzielna grozi mniej niebezpieczeństw, co oznacza większe możliwości zaspokojenia wszystkich czterech potrzeb. Na przykład kariera zawodowa może stawiać przed człowiekiem wiele celów i dawać duże poczucie skuteczności, ale ma niewielkie znaczenie z punktu widzenia wyznawanych wartości. W ciekawej i satysfakcjonującej pracy możemy bowiem się realizować, ale rzadko uzyskamy silne przekonanie o tym, co jest dobre, a co złe. Owo poczucie wartości i równowagi może natomiast zostać zapewnione chociażby przez udane życie rodzinne (kierowanie się dobrem dzieci jest powszechnie uznawane za właściwy wybór).

Wśród nastolatków zdrowie psychiczne silnie wiąże się z poczuciem sensu życia (Brassai et al., 2011). Poszukiwanie go stanowi podstawową motywację w życiu człowieka, a jego brak może prowadzić do wielu zaburzeń, m.in. do wchodzenia w rolę ofiary bądź sprawcy przemocy rówieśniczej. Zastraszanie wśród uczniów to zjawisko bardzo stare. Fakt, że niektóre dzieci są często i systematycznie nękane oraz atakowane przez inne dzieci, został opisany w licznych pracach. Także wielu dorosłych przyznaje, że mają oni tego typu przykre doświadczenia $\mathrm{z}$ lat szkolnych. Chociaż wiele osób jest zaznajomionych $\mathrm{z}$ problemem nękania, to jednak 
people, it was not until early 1970 s that attempts were made to systematically investigate this phenomenon (Olweus, 1978, 1993a). For a long time, these attempts were largely limited to Scandinavia. However, in the 1980s and and early 1990s the problem of bullying among school-age children received considerably greater attention, particularly in Japan, United Kingdom, Australia and United States of America, and also in other countries. At present, there are signs of growing social and scientific interest in problems related to violence perpetrators and victims in many parts of the world (Jiménez-Barbero et al., 2016). Over the past two decades, the number of papers on bullying in the school environment has increased significantly (Janssen et al., 2004; Kaltiala-Heino et al., 2000; Mazur et al., 2017; Olweus, 1994). Special attention has been given to bullying which can be defined as repeated aggressive behaviour directed against one or more students who are weaker and unable to defend themselves. They can take the form of physical, verbal or emotional aggression. The most recent form of harassment where bullies use technology to target their victim is cyberbullying - a phenomenon emerging in the wake of technological progress (Selkie et al., 2016). Some of the most common consequences of being bullied at school include physical or mental trauma, damage to property, sense of humiliation, social alienation, impaired school performance or even involvement in risky behaviours (Fekkes et al., 2005; Gini and Pozzoli, 2013; JiménezBarbero et al., 2016; Vaillancourt et al., 2013). Published studies address primarily the prevalence of harassment in various populations and its determinants (Elgar et al., 2009; Harel-Fisch et al., 2011; Molcho et al., 2009). The number of reviews on the background underlying this phenomenon and the effectiveness of intervention programmes is also growing (Chalamandaris and Piette, 2015; JiménezBarbero et al., 2016; Park-Higgerson et al., 2008; Ttofi and Farrington, 2011).

Bullying is a relatively common problem among schoolage children. Approximately $15 \%$ of Swedish children take on the role of perpetrators or victims of peer violence (Olweus, 1993a). Bullying can be regarded a form of intentional and unwanted abuse aimed at causing pain and anxiety to another person. Bullying is committed repeatedly by one or more children (Olweus, 1993a). Research on the short- and long-term effects of bullying has shown that it is a source of great distress for the victim, and it is associated with negative psychological, social and physical consequences both in the child's present life and later in life (Graham and Juvonen, 1998; Kumpulainen et al., 1998; Olweus, 1993b; Rigby, 2003). Crucially, even though harassment of this type is highly prevalent and has destructive effects on children, it has received little attention as a health concern. Also there is a lack of studies examining associations between the consequences of bullying and the general quality of life. The analyses focus primarily on victims, however, some attention has also been given to possible social consequences affecting those who engage dopiero na początku lat 70. ubiegłego stulecia podjęto starania o systematyczne zbadanie tego zjawiska (Olweus, 1978, 1993a). Przez długi czas próby te były w dużej mierze ograniczone do Skandynawii. Jednak w latach 80. i na początku 90. XX wieku kwestia nękania dzieci w wieku szkolnym skupiła na sobie znacznie większą uwagę - w Japonii, Anglii, Australii, Stanach Zjednoczonych i innych krajach. Obecnie w wielu częściach świata obserwuje się wyraźne oznaki coraz silniejszego zainteresowania społecznego oraz badawczego problemami sprawców i ofiar (Jiménez-Barbero et al., 2016). Przez ostatnie dwie dekady liczba dokumentów o nękaniu w środowisku szkolnym znacznie wzrosła (Janssen et al., 2004; Kaltiala-Heino et al., 2000; Mazur et al., 2017; Olweus, 1994). Szczególną uwagę poświęca się zjawisku prześladowania, zdefiniowanemu jako powtarzające się zachowania agresywne skierowane do drugiego ucznia lub do grupy uczniów słabszych i niezdolnych do obrony. Mogą one przybrać formę agresji fizycznej, werbalnej lub emocjonalnej; swoje miejsce znajduje tu też cyberprzestępczość, która jest najnowszym przejawem agresji, związanym $\mathrm{z}$ intensywnym postępem technologicznym (Selkie et al., 2016). Konsekwencjami prześladowania w szkole są zazwyczaj urazy fizyczne lub psychiczne, zniszczenia mienia, poczucie upokorzenia, wyobcowanie społeczne, pogarszanie się wyników w nauce, a nawet zaangażowanie w zachowania ryzykowne (Fekkes et al., 2005; Gini i Pozzoli, 2013; Jiménez-Barbero et al., 2016; Vaillancourt et al., 2013). Opublikowane badania odnoszą się głównie do częstości występowania zastraszania w różnych populacjach oraz do jego determinantów (Elgar et al., 2009; Harel-Fisch et al., 2011; Molcho et al., 2009). Rośnie także liczba przeglądów dotyczących tła tego zjawiska i skuteczności programów interwencyjnych (Chalamandaris i Piette, 2015; Jiménez-Barbero et al., 2016; Park-Higgerson et al., 2008; Ttofi i Farrington, 2011).

Prześladowanie jest stosunkowo powszechnym problemem wśród dzieci w wieku szkolnym. Około 15\% szwedzkich dzieci przyjmuje rolę sprawców lub ofiar przemocy rówieśniczej (Olweus, 1993a). Prześladowanie można uznać za formę umyślnego, niechcianego nadużycia, które ma na celu wywołanie bólu i niepokoju u innego człowieka. Dokonywane jest ono wielokrotnie przez jedno lub więcej dzieci (Olweus, 1993a). Badania nad krótko- i długoterminowymi skutkami znęcania wykazały, że stanowi ono źródło wielkiego niepokoju dla ofiary i wiąże się z negatywnymi konsekwencjami psychologicznymi, społecznymi i fizycznymi zarówno w obecnym życiu dziecka, jak i podczas jego późniejszej egzystencji (Graham i Juvonen, 1998; Kumpulainen et al., 1998; Olweus, 1993b; Rigby, 2003). Ponadto zastraszanie - choć cechuje się wysoką częstością występowania i destruktywnym wpływem na dzieci - zyskuje niewielką uwage jako kwestia zdrowotna. Wyraźnie brakuje też badań dotyczących związków między skutkami prześladowania a ogólną jakością życia. Analizy koncentrują się przede wszystkim na ofiarach, jednak pewną uwagę poświęcono również możliwym konsekwencjom 
in bullying or commit abuse. Therefore, the term "victim" may refer to both the person experiencing peer violence and the perpetrator (Rigby, 2003). The peer group plays a particularly important role during the period of adolescence, and problematic peer-to-peer relations contribute to a range of serious psychological and behavioral problems during puberty (Olweus, 1993b).

\section{AIM OF THE STUDY}

The aim of the study was to assess whether the sense of the meaning in life can be a factor protecting middle school adolescents from taking on the role of perpetrator or victim of peer violence. The following three study questions were formulated:

1. What is the level of sense of meaning in life among Polish middle school pupils depending on their gender and age?

2. How often do Polish middle school pupils take on the role of victim or perpetrator of peer violence, and to what extent are age and gender the differentiating factors for (the frequency of) taking on the role of perpetrator or victim of peer violence?

3. Is taking on the role of perpetrator or victim of violence correlated with the level of sense of meaning in life?

\section{MATERIAL}

The questionnaire-based study was conducted in 2015 within the framework of the National Science Centre (NCN) project no. 2013/09/B/HS6/03438 and involved a total of 4,085 pupils ( $52 \%$ girls) from 70 middle schools located in all Polish voivodeships. The project entitled "Physical and social environment and the quality of school functioning and their effect on the subjective health and health behaviours of teenagers - the application of structural and path models estimated on hierarchically structured data" was implemented under a contract with the NCN within the OPUS 5 competition. The individual data of children attending the middle schools from all over Poland which were randomly selected for the project are derived from the questionnaire "Health and school" which was completed by grade 1-3 pupils. The project was supervised by IMiD Professor Joanna Mazur, PhD (hab.).

\section{METHOD}

The analyses performed in the study addressed the following problems:

1. Sense of meaning in life - evaluated using the Purpose in Life Test (PIL) by J.C. Crumbaugh and L.T. Maholick (Crumbaugh and Maholick, 1964), Polish adaptation by Z. Płużek. The study was based on an abbreviated univariate version of the scale, the psychometric analysis of which had been carried out under the supervision of J. Życińska (Życińska and Januszek, 2011). It consists społecznym dla tych, którzy sami się znęcają lub dopuszczają się nadużyć. Dlatego termin „ofiara” może być określeniem dotyczącym zarówno osoby ulegającej przemocy rówieśniczej, jak i jej sprawcy (Rigby, 2003). Grono rówieśników ma szczególnie duże znaczenie w okresie adolescencji, a problematyczne relacje $\mathrm{w}$ tej grupie przekładają się na szereg poważnych problemów psychologicznych i behawioralnych w okresie dojrzewania (Olweus, 1993b).

\section{CEL PRACY}

Celem badania było sprawdzenie, czy poczucie sensu życia może stanowić czynnik chroniący młodzież gimnazjalną przed wchodzeniem w rolę sprawcy lub ofiary przemocy rówieśniczej. Postawiono trzy pytania badawcze:

1. Jaki jest poziom poczucia sensu życia wśród polskich gimnazjalistów w zależności od płci i wieku?

2. Jak często polscy gimnazjaliści wchodzą w rolę ofiary lub sprawcy przemocy rówieśniczej oraz $\mathrm{w}$ jakim stopniu wiek i płeć różnicują (częstość przyjmowania) przyjmowanie roli sprawcy lub ofiary przemocy rówieśniczej?

3. Czy wchodzenie w rolę sprawcy lub ofiary przemocy związane jest $\mathrm{z}$ poziomem poczucia sensu życia?

\section{MATERIA}

Badaniem ankietowym - zrealizowanym w 2015 roku w ramach projektu Narodowego Centrum Nauki (NCN nr 2013/09/B/HS6/03438) - objęto 4085 uczniów z 70 gimnazjów zlokalizowanych we wszystkich województwach w Polsce (52\% stanowiły dziewczęta). Projekt pt. „Środowisko fizyczne i społeczne oraz jakość funkcjonowania szkoły a zdrowie subiektywne i zachowania zdrowotne nastolatków - zastosowanie modeli strukturalnych i ścieżkowych szacowanych na danych o strukturze hierarchicznej" zrealizowany został w ramach umowy z NCN w konkursie OPUS 5. Dane indywidualne dzieci uczęszczających do wylosowanych gimnazjów z terenu całego kraju pochodzą z ankiety „Zdrowie i szkoła”, przeprowadzonej wśród uczniów klas I-III. Projektem kierowała dr hab. prof. IMiD Joanna Mazur.

\section{METODA}

Podjęte w pracy analizy dotyczyły następujących kwestii:

1. Poczucie sensu życia - badane przy użyciu Testu Sensu Życia (Purpose in Life Test, PIL) autorstwa J.C. Crumbaugha i L.T. Maholicka (Crumbaugh i Maholick, 1964), w polskiej adaptacji Z. Płużek. Zastosowano tu skróconą, jednoczynnikową wersję skali, której analiza psychometryczna została przeprowadzona pod kierunkiem J. Życińskiej (Życińska i Januszek, 2011). Składa się ona z 6 stwierdzeń, ocenianych w skali 0-7 punktów, odnoszących się bezpośrednio do posiadania celu oraz odnajdywania sensu i roli w życiu. Indeks sumaryczny przyjmuje zakres 0-36 punktów. Im wyższy wynik uzyskany na skali, 
relating directly to having a goal and finding the meaning and purpose in life. The total index takes the range of $0-36$ points. The higher the score obtained on the scale, the higher the level of sense of meaning in life in the studied adolescents. For the purpose of the study, a dichotomous distinction was adopted. Scores of at least 26 points were interpreted as a high sense of meaning in life. Scores below 26 points were regarded as at most moderate sense of meaning in life. Based on the considerations given above, the following version of the scale was used in the study:

- In life, I have: no goals or aims (1) - clear goals and aims (7).

- My personal existence is: utterly meaningless, without purpose (1) - purposeful and meaningful (7).

- Every day is: constantly new and different (7) - exactly the same (1).

- In achieving life goals, I have: made no progress whatever (1) - progressed to complete fulfilment (7).

- I regard my ability to find a purpose or mission in life as: very great (7) - practically none (1).

- I have discovered: no mission or purpose in life (1) - a satisfying life purpose (7).

The scale used is described more fully in a separate study (Życińska and Januszek, 2011).

2. Peer violence was evaluated by means of two questions referring to the two dimensions of being either the perpetrator (Over the past 2 months, how often have you engaged in bullying another pupil or pupils at school?) or the victim of violence (Over the past 2 months, how often have you yourself been bullied at school?). The questions could be answered by selecting one of the following options: not happened over the past 2 months; once or twice; 2-3 times a month; more or less once a week; a few times a week.

For the purpose of the study, the answers were categorised as follows: not a perpetrator/victim of violence; at least once or twice (over the past 2 months); at least once a week ("more or less once" and more frequently).

Questions regarding peer violence were derived from the Polish version of the research protocol employed in the international study Health Behaviour in School-aged Children (HBSC) in which they had been used in similar phrasing since 1990 (Mazur and Małkowska-Szkutnik, 2011). The study is now in its $8^{\text {th }}$ round, with Poland included as one of more than 40 participating countries.

Both univariate and multivariate analyses - including logistic regression - were performed to determine the risk of being a perpetrator or victim of peer violence at least once during the 2 months preceding the study. The multivariate model of logistic regression also included gender and middle school grade (from 1 to 3 ) as controlled variable. The reference categories were: lack of a high level of sense of meaning in life, middle school grade 1 and gender (boys). In all the analyses $p<0.05$ was considered statistically significant. SPSS v. 17 was used to study the data. tym wyższym poziomem poczucia sensu życia charakteryzuje się badana młodzież. Na cele niniejszej pracy przyjęto podział dychotomiczny. Wysoki poziom poczucia sensu życia stwierdzano w przypadku co najmniej 26 punktów. Wartości poniżej 26 punktów uznawano za najwyżej przeciętny poziom poczucia sensu życia. Poniższe stwierdzenia składają się na zastosowaną w badaniu wersję skali:

- W życiu: nie mam żadnych celów ani do niczego nie dąże (1) - mam bardzo wyraźne cele i dążenia (7).

- Moje istnienie jest: zupetnie bezcelowe (1) - celowe i sensowne (7).

- Każdy dzień: niesie ze soba coś nowego (7) - jest zawsze taki sam (1).

- W dążeniu do celów życiowych: nigdy nie miałem powodzenia (1) - udało mi się zaspokajać moje potrzeby (7).

- Uważam, że moje szanse na znalezienie sensu życia, celu $i$ roli $w$ życiu: są bardzo duże (7) - sa praktycznie $\dot{z} a d-$ ne (1).

- Doszedłem do wniosku, że: brak mi celu (1) - mam wyraźne cele dające pełne zadowolenie (7).

Dokładniejsze informacje dotyczące zastosowanej skali zostały przedstawione w odrębnym opracowaniu (Życińska i Januszek, 2011).

2. Przemoc rówieśnicza - analizowana za pomocą dwóch pytań odnoszących się do następujących wymiarów: bycia sprawcą (Jak często zdarzyło się $w$ szkole $w$ ciagu ostatnich 2 miesięcy, że uczestniczyłeś $w$ dręczeniu innego ucznia lub uczniów?) oraz bycia ofiarą przemocy (Jak często zdarzyło się $w$ szkole $w$ ciagu ostatnich 2 miesięcy, że ty sam byłeś dręczony?). Można było na nie odpowiedzieć, wybierając jedną z następujących opcji: nie zdarzyło się $w$ ciagu ostatnich 2 miesięcy; zdarzyło się 1 lub 2 razy; 2-3 razy w miesiacu; mniej więcej 1 raz w tygodniu; kilka razy w tygodniu. $\mathrm{Na}$ potrzeby niniejszego opracowania odpowiedzi skategoryzowano następująco: nie był/była sprawcą/ofiarą przemocy; tak, zdarzyło się co najmniej 1 lub 2 razy (w ciągu ostatnich 2 miesięcy); tak, co najmniej $1 \mathrm{raz}$ w tygodniu („mniej więcej 1 raz” i częściej).

Pytania dotyczące przemocy rówieśniczej zostały zaczerpnięte z polskiej wersji protokołu badawczego pochodzącego z międzynarodowych badań Health Behaviour in School-aged Children (HBSC), w których są stosowane w podobnym brzmieniu od 1990 roku (Mazur i Małkowska-Szkutnik, 2011). Obecnie odbywa się 8. runda tych badań, a Polska jest jednym z ponad 40 krajów biorących w nich udział.

Zastosowano analizy jednowymiarowe oraz wielowymiarowe, w tym regresję logistyczną, w celu określenia ryzyka bycia sprawcą lub ofiarą przemocy rówieśniczej przynajmniej raz w ciągu 2 miesięcy przed badaniem. Do wielowymiarowego modelu regresji logistycznej włączono również płeć oraz klasę gimnazjum (od I do III) jako zmienne kontrolowane. Kategoriami odniesienia były: brak wysokiego poziomu poczucia sensu życia, I klasa gimnazjum i płeć - chłopcy. We wszystkich analizach za poziom istotności przyjęto $p<0,05$. Zastosowano program SPSS v. 17 . 


\begin{tabular}{|c|c|c|c|c|c|c|c|}
\hline & $\begin{array}{c}\text { Boys } \\
\boldsymbol{n}=\mathbf{1 , 9 6 2} \\
\text { Chłopcy }\end{array}$ & $\begin{array}{c}\text { Girls } \\
\boldsymbol{n}=\mathbf{2 , 1 2 3} \\
\text { Dziewczęta }\end{array}$ & $p$ & $\begin{array}{c}\text { Grade } 1 \\
n=1,310 \\
\text { I klasa }\end{array}$ & $\begin{array}{c}\text { Grade } 2 \\
n=1,390 \\
\text { II klasa }\end{array}$ & $\begin{array}{c}\text { Grade } 3 \\
n=1,250 \\
\text { II klasa }\end{array}$ & $p$ \\
\hline \multicolumn{8}{|c|}{$\begin{array}{l}\text { Mean values for the level of sense of meaning in life } \\
\text { Wartości średnie dla poziomu poczucia sensu życia }\end{array}$} \\
\hline $\begin{array}{l}\text { Mean (standard deviation) } \\
\text { Średnia (odchylenie standardowe) }\end{array}$ & $25.1(7.1)$ & $24.3(7.5)$ & 0.001 & $25.2(7.3)$ & $24.4(7.4)$ & $24.4(7.4)$ & 0.014 \\
\hline \multicolumn{8}{|c|}{$\begin{array}{l}\text { Perpetrating peer violence (\% of study group) } \\
\text { Stosowanie przemocy rówieśniczej (\% badanych) }\end{array}$} \\
\hline $\begin{array}{l}\text { Not a perpetrator of violence } \\
\text { Nie był/była sprawca przemocy }\end{array}$ & 63.2 & 82.2 & \multirow{3}{*}{$\leq 0.001$} & 73.9 & 71.0 & 74.8 & \multirow{3}{*}{0.247} \\
\hline $\begin{array}{l}\text { At least once or twice } \\
\text { Tak, zdarzyło się co najmniej } 1 \text { lub } 2 \text { razy }\end{array}$ & 20.4 & 11.5 & & 15.4 & 17.0 & 14.6 & \\
\hline $\begin{array}{l}\text { At least once a week } \\
\text { Tak, co najmniej } 1 \text { raz w tygodniu }\end{array}$ & 16.4 & 6.3 & & 10.7 & 12.0 & 10.6 & \\
\hline \multicolumn{8}{|c|}{$\begin{array}{l}\text { Experiencing peer violence (\% of study group) } \\
\text { Doznawanie przemocy rówieśniczej (\% badanych) }\end{array}$} \\
\hline $\begin{array}{l}\text { Not a victim of violence } \\
\text { Nie był/była ofiara przemocy }\end{array}$ & 66.5 & 73.6 & \multirow{3}{*}{$\leq 0.001$} & 69.1 & 68.0 & 73.8 & \multirow{3}{*}{0.016} \\
\hline $\begin{array}{l}\text { At least once or twice } \\
\text { Tak, zdarzyło się co najmniej } 1 \text { lub } 2 \text { razy }\end{array}$ & 17.7 & 16.3 & & 17.3 & 18.6 & 14.8 & \\
\hline $\begin{array}{l}\text { At least once a week } \\
\text { Tak, co najmniej } 1 \text { raz w tygodniu }\end{array}$ & 15.8 & 10.1 & & 13.6 & 13.4 & 11.4 & \\
\hline
\end{tabular}

Tab. 1. Sense of meaning in life among middle school pupils, and perpetrating and experiencing peer violence in the last 2 months (by gender and age)

Tab. 1. Poczucie sensu życia wśród gimnazjalistów oraz stosowanie i doznawanie przemocy rówieśniczej w ciagu ostatnich 2 miesięcy (wg płci $i$ wieku)

\section{Perpetrator of violence (\% of study group)}

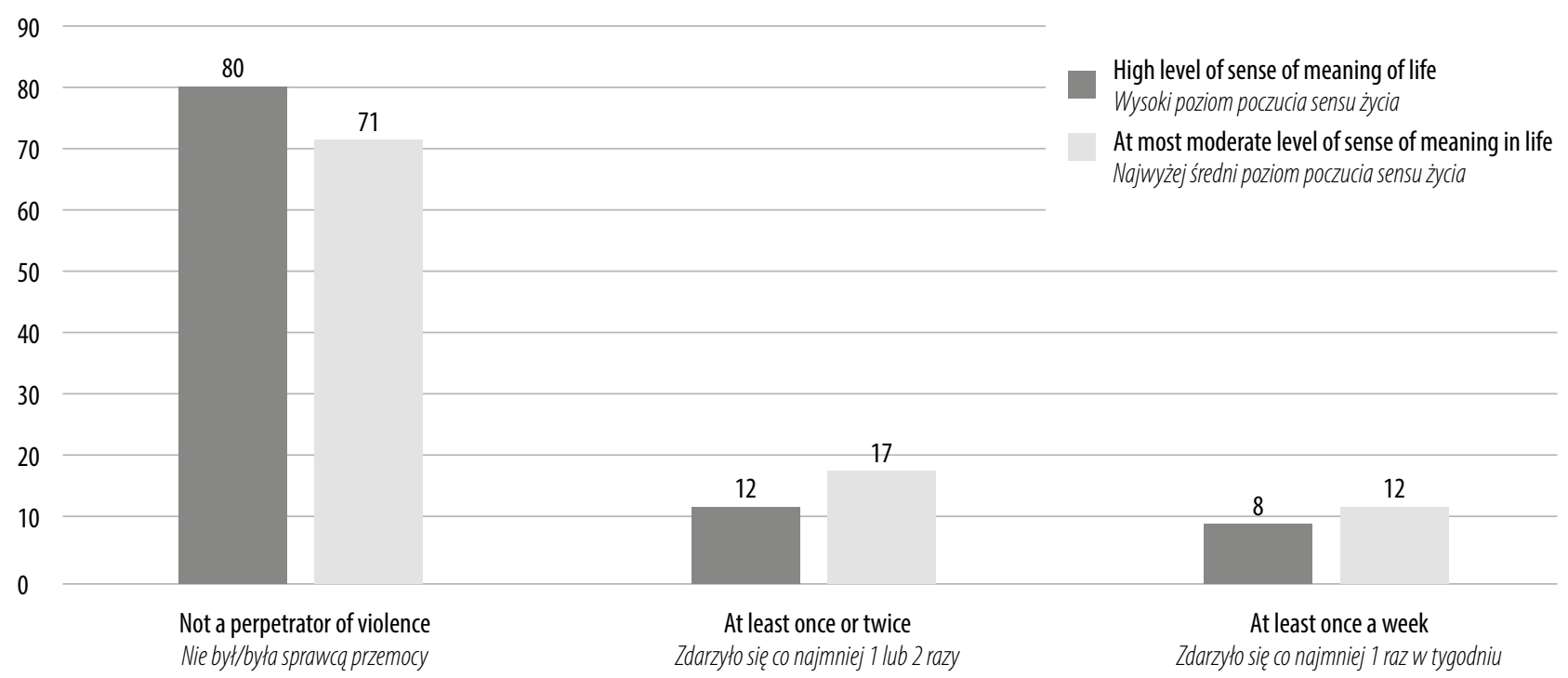

Fig. 1. Being a perpetrator of peer violence during the 2 months preceding questionnaire completion depending on the level of sense of meaning in life

Ryc. 1. Wchodzenie $w$ ciagu ostatnich 2 miesięcy przed badaniem ankietowym $w$ rolę sprawcy przemocy rówieśniczej $w$ zależności od poziomu poczucia sensu życia 


\section{RESULTS}

The mean score obtained for the sense of meaning in life among the studied pupils was 24.7 (score range: $0-36$ points). The boys and grade 1 pupils had a significantly higher level of sense of meaning in life than the girls and grade 2 and 3 pupils (Tab. 1). In the study group of 4,085 middle school pupils $26.8 \%$ were perpetrators and $29.8 \%$ were victims of peer violence at least once during the preceding 2 months. Boys were found to be both perpetrators and victims of peer violence significantly more frequently than girls $(p<0.001)$ (Tab. 1$)$.

Over one-third of boys and slightly less than one-fourth of girls were perpetrators of peer violence during the preceding 2 months. Two-thirds of boys and nearly three-fourths of girls did not experience any peer violence. Every $6^{\text {th }}$ middle school boy and every $10^{\text {th }}$ middle school girl were victims of peer violence at least once a week. Also, every $6^{\text {th }}$ adolescent boy and every $17^{\text {th }}$ adolescent girl admitted to bullying their peers on a frequent basis (at least once a week).

Middle school grade 3 pupils experienced violence from their peers significantly less frequently than grade 1 and 2 pupils $(p=0.016)$. Over two-thirds of grade 1 and 2 pupils and nearly three-fourths of grade 3 pupils never experienced any harassment from their peers.

A significant relationship was found between being the perpetrator or victim of violence and the level of sense of meaning in life $(p \leq 0.001)$ (Figs. 1,2). Over three-fourths of pupils with a high level of sense of meaning in life never experienced violence from their peers and never perpetrated violence toward them.

\section{WYNIKI}

Poziom poczucia sensu życia wśród badanych uczniów wyniósł średnio 24,7 punktu (zakres sumaryczny: 0-36 punktów), przy czym chłopcy oraz uczniowie z klas I gimnazjum charakteryzowali się istotnie wyższym jego poziomem niż dziewczęta i uczniowie z klas II i III (tab. 1).

Spośród 4085 gimnazjalistów co najmniej raz w ciągu ostatnich 2 miesięcy 26,8\% było sprawcą, a 29,8\% padło ofiarą przemocy rówieśniczej. Chłopcy istotnie częściej niż dziewczęta występowali w roli zarówno sprawców, jak i ofiar przemocy rówieśniczej $(p<0,001)$ (tab. 1).

W ciągu ostatnich 2 miesięcy sprawcą przemocy rówieśniczej co najmniej raz były ponad $1 / 3$ chłopców oraz nieco mniej niż $1 / 4$ dziewcząt. Nie doświadczyły jej $2 / 3$ chłopców oraz prawie $3 / 4$ dziewcząt. Co 6 . uczeń i co 10 . uczennica znaleźli się w roli ofiary przemocy rówieśniczej co najmniej raz w tygodniu. Natomiast do bycia sprawcą częstych aktów prześladowania (co najmniej raz w tygodniu) przyznali się co 6. nastolatek i co 17. nastolatka.

Uczniowie klasy III gimnazjum doznawali przemocy ze strony rówieśników istotnie rzadziej niż ci uczęszczający do klas I oraz II $(p=0,016)$. Ponad $2 / 3$ uczniów I i II klasy gimnazjum oraz blisko 3/4 uczniów klasy III nigdy nie doznało nękania ze strony rówieśników.

Stwierdzono istotny związek między byciem sprawcą lub ofiarą przemocy a poziomem poczucia sensu życia $(p \leq 0,001)$ (ryc. 1, 2). Ponad 3/4 gimnazjalistów z wysokim jego poziomem nigdy nie doświadczyło przemocy ze strony rówieśników oraz nigdy nie było jej sprawcą.

\section{Victim of violence (\% of study group)}

Ofiara przemocy (\% badanych)

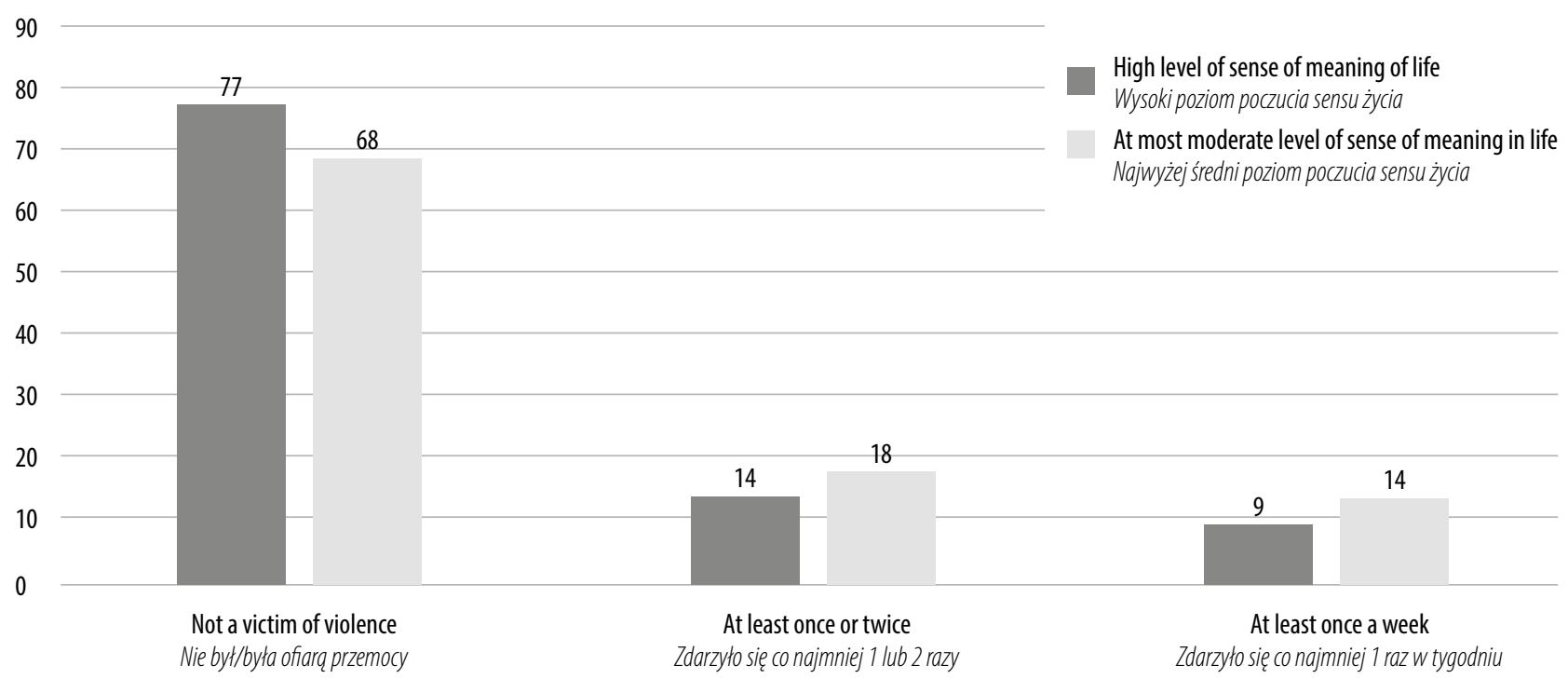

Fig. 2. Being a victim of peer violence during the 2 months preceding questionnaire completion depending on the level of sense of meaning in life

Ryc. 2. Wchodzenie $w$ ciagu ostatnich 2 miesięcy przed badaniem ankietowym $w$ rolę ofiary przemocy rówieśniczej $w$ zależności od poziomu poczucia sensu życia 


\begin{tabular}{|c|c|c|c|c|c|}
\hline \multicolumn{2}{|c|}{$\begin{array}{l}\text { Independent variable } \\
\text { Zmienne objaśniajace }\end{array}$} & $\begin{array}{l}\text { Reference category } \\
\text { Kategoria odniesienia }\end{array}$ & $p$ & $O R$ & $\begin{array}{c}\text { Confidence interval 95\% } \\
\text { (CI) (OR) } \\
\text { Przedział ufności 95\% } \\
\text { (confidence interval, (I) (OR) }\end{array}$ \\
\hline \multicolumn{6}{|c|}{$\begin{array}{l}\text { Victim of violence } \\
\text { Ofiara przemocy }\end{array}$} \\
\hline $\begin{array}{l}\text { Level of sense of meaning in life } \\
\text { Poziom poczucia sensu życia }\end{array}$ & $\begin{array}{c}\text { High level of sense } \\
\text { of meaning in life } \\
\text { Wysoki poziom poczucia sensu życia }\end{array}$ & $\begin{array}{l}\text { At most moderate level of sense } \\
\text { of meaning in life } \\
\text { Najwyżej przeciętny poziom } \\
\text { poczucia sensu życia }\end{array}$ & $<0.001$ & 0.52 & $0.45-0.60$ \\
\hline $\begin{array}{l}\text { Gender } \\
\text { Płéc }\end{array}$ & $\begin{array}{c}\text { Girls } \\
\text { Dziewczęta }\end{array}$ & $\begin{array}{l}\text { Boys } \\
\text { Chłopcy }\end{array}$ & $<0.001$ & 0.70 & $0.60-0.80$ \\
\hline \multirow{2}{*}{$\begin{array}{l}\text { Middle school grade } \\
\text { Klasa gimnazjum }\end{array}$} & $\begin{array}{l}\text { Grade } 2 \\
\text { II klasa }\end{array}$ & \multirow{2}{*}{$\begin{array}{l}\text { Grade } 1 \\
\text { I klasa }\end{array}$} & 0.816 & 0.98 & $0.82-1.15$ \\
\hline & $\begin{array}{l}\text { Grade } 3 \\
\text { III klasa }\end{array}$ & & 0.001 & 0.74 & $0.62-0.89$ \\
\hline \multicolumn{6}{|c|}{$\begin{array}{l}\text { Perpetrator of violence } \\
\text { Sprawca przemocy }\end{array}$} \\
\hline $\begin{array}{l}\text { Level of sense of meaning in life } \\
\text { Poziom poczucia sensu życia }\end{array}$ & $\begin{array}{l}\text { High level of sense of meaning } \\
\text { in life } \\
\text { Wysoki poziom poczucia sensu życia }\end{array}$ & $\begin{array}{l}\text { At most moderate level of sense } \\
\text { of meaning in life } \\
\text { Najwyżej przeciętny poziom } \\
\text { poczucia sensu życia }\end{array}$ & $<0.001$ & 0.61 & $0.50-0.73$ \\
\hline $\begin{array}{l}\text { Gender } \\
\text { Płéc }\end{array}$ & $\begin{array}{c}\text { Girls } \\
\text { Dziewczęta }\end{array}$ & $\begin{array}{l}\text { Boys } \\
\text { Chłopcy }\end{array}$ & $<0.001$ & 0.36 & $0.31-0.42$ \\
\hline \multirow{2}{*}{$\begin{array}{l}\text { Middle school grade } \\
\text { Klasa gimnazjum }\end{array}$} & $\begin{array}{l}\text { Grade } 2 \\
\text { II klasa }\end{array}$ & \multirow{2}{*}{$\begin{array}{l}\text { Grade } 1 \\
\text { I klasa }\end{array}$} & 0.239 & 1.116 & $0.93-1.34$ \\
\hline & $\begin{array}{l}\text { Grade } 3 \\
\text { III klasa }\end{array}$ & & 0.327 & 0.90 & $0.75-1.10$ \\
\hline
\end{tabular}

Tab. 2. Results of multivariate logistic regression analysis evaluating the probability of taking on the role of victim or perpetrator of peer violence at least 1-2 times during the preceding 2 months

Tab. 2. Wyniki wielowymiarowej regresji logistycznej do oceny prawdopodobieństwa wchodzenia w rolę ofiary lub sprawcy przemocy rówieśniczej co najmniej 1-2 razy w ciagu ostatnich 2 miesięcy

Regression analysis showed a significantly lower probability ( $p \leq 0.001$ ) of being a victim (odds ratio, $O R=0.52$ ) or perpetrator $(O R=0.61)$ of peer violence (at least $1-2$ times) in adolescents with a high sense of meaning in life during the 2-month period preceding questionnaire completion (Tab. 2). A significantly lower probability ( $p \leq 0.001$ ) of taking on the role of victim or perpetrator of violence was found in girls compared to boys (OR 0.70 and 0.36 , respectively).

The risk of being a victim of violence is also significantly decreased in middle school grade 3 pupils compared to grade 1 pupils $(O R=0.74)$.

\section{DISCUSSION}

The analyses presented in this paper rely on the results obtained in the questionnaire-based study which was conducted in 2015 within the framework of the NCN project no. $2013 / 09 / \mathrm{B} / \mathrm{HS} 6 / 03438$ in a group of 4,085 pupils (52\% girls) from 70 middle schools located in all Polish voivode-
Analiza regresji wykazała u młodzieży z wysokim poczuciem sensu życia istotnie mniejsze prawdopodobieństwo $(p \leq 0,001)$ bycia ofiarą (iloraz szans, odds ratio, $O R=0,52)$ lub sprawcą $(O R=0,61)$ przemocy rówieśniczej (co najmniej 1-2 razy) w ciągu ostatnich 2 miesięcy przed badaniem ankietowym (tab. 2). Stwierdzono istotnie mniejsze prawdopodobieństwo $(p \leq 0,001)$ wchodzenia w rolę ofiary lub sprawcy przemocy wśród dziewcząt w porównaniu z chłopcami (OR odpowiednio 0,70 i 0,36).

Ryzyko bycia ofiarą przemocy istotnie zmniejsza również fakt uczęszczania do klasy III gimnazjum, w porównaniu z uczniami klasy I $(O R=0,74)$.

\section{OMÓWIENIE}

W niniejszej analizie posłużono się wynikami badania ankietowego zrealizowanego w 2015 roku w ramach grantu NCN (nr 2013/09/B/HS6/03438) wśród 4085 uczniów z 70 gimnazjów zlokalizowanych we wszystkich województwach w Polsce (52\% badanych stanowiły dziewczęta). W pracy postawiono trzy pytania badawcze. 
was related to the level of sense of meaning in life. The boys and middle school grade 1 pupils were found to have a significantly higher level of sense of meaning in life than girls and grade 2 and 3 pupils. Different findings were obtained in one of the previous questionnaire-based studies conducted in a group of 643 middle school grade 1 and 3 pupils aged 13-17 years, which investigated the sense of meaning in life and subjective vitality and socioeconomic status among middle school adolescents (Zawadzka and Korzycka, 2018). The study found that neither gender nor school grade were factors differentiating the variable of the sense of meaning in life. It needs to be noted, however, that the cited study involved a different 4 -item version of the PiL scale, with the assumption that scores above 20 points indicated a high sense of meaning in life. Also, the study sample was 7 times smaller. However, similar findings were obtained by the authors in their previous study (Zawadzka et al., 2017). The average level of the sense of meaning in life among the pupils studied in the cited paper was 24.7 points (total range: $0-36$ ). The variable reached a considerably higher value among boys than girls. Both boys and grade 1 pupils rated their health as excellent more frequently than girls and older pupils. Similar results were obtained by the authors in their earlier study (Zawadzka et al., 2016). The score obtained in the group of boys was higher than in the group of girls as well. The pupils who were satisfied with their lives and rarely experienced subjective complaints had a significantly higher mean level of sense of meaning in life than those who were dissatisfied with their lives and experienced complaints with a moderate and high frequency. Rathi and Rastogi (2007) reported different results in their analyses. In their study conducted among Indian teenagers the authors found girls to have a higher sense of purpose in life than boys. Differences in this aspect may be due to the fact that the authors employed a different research tool: Personal Meaning Profile (PMP), a 57-item scale consisting of seven subscales proposed by Wong (1998). PMP is an extensive scale comprising a number of dimensions including achievements, relationships, religion, self-transcendence, self-acceptance, intimacy and fair treatment. Another factor is that the study was based on a significantly smaller study sample comprising only 104 adolescents. Cultural differences can also be regarded as a contributing factor. The main discrepancy seems to be the fact that girls in India frequently suffer from professional and social exclusion, and often fight even for the most fundamental human rights. Consequently, they may recognise their individual existence and its manifestations as a great value, which in turn may lead to a higher sense of purpose in life.

Exploring the question phrased as "How often do Polish middle school pupils take on the role of victim or perpetrator of peer violence, and to what extent are age and gender the differentiating factors for these behaviours?", it was found that during the preceding 2-month period in the group of 4,085 middle school pupils studied approximately every $4^{\text {th }}(26.8 \%)$ was a perpetrator, and $29.8 \%$ were victims
Odpowiadając na pierwsze $\mathrm{z}$ nich, dotyczące poziomu poczucia sensu życia, stwierdzono, że chłopcy oraz uczniowie z klas I gimnazjum charakteryzowali się istotnie wyższym jego poziomem niż dziewczęta i uczniowie z klas II i III. W jednym z poprzednich badań ankietowych - przeprowadzonych w grupie 643 uczniów klas I oraz III gimnazjum w wieku 13-17 lat i dotyczących poczucia sensu życia oraz subiektywnej witalności i statusu socjoekonomicznego gimnazjalistów - uzyskano odmienne wyniki (Zawadzka i Korzycka, 2018). Stwierdzono bowiem, że płeć oraz poziom klasy nie różnicują zmiennej, jaką jest poczucie sensu życia. W cytowanym badaniu użyto jednak innej wersji skali PiL, 4-itemowej, przyjmując, że wynik powyżej 20 punktów oznacza wysoki poziom poczucia sensu życia. Ponadto analizie została poddana prawie 7 razy mniejsza próba. Natomiast w jeszcze wcześniejszych badaniach autorzy uzyskali podobne wyniki (Zawadzka et al., 2017). W cytowanej pracy średni poziom poczucia sensu życia wśród badanych uczniów wyniósł 24,7 punktu (zakres podsumowania: 0-36). Zmienna ta osiągnęła znacznie wyższą wartość wśród chłopców niż dziewcząt. Chłopcy oraz uczniowie klasy I ocenili swoje zdrowie jako doskonałe częściej niż dziewczęta i starsi uczniowie. Również w jeszcze wcześniejszym badaniu autorzy uzyskali podobne wyniki (Zawadzka et al., 2016). Tu także chłopcy osiągnęli wyższą punktację niż dziewczęta. Uczniowie zadowoleni ze swojego życia i rzadko odczuwający dolegliwości subiektywne charakteryzowali się istotnie wyższym średnim poziomem sensu życiu niż ci, którzy byli niezadowoleni ze swojego życia oraz przeciętnie i często odczuwali dolegliwości.

Z kolei Rathi i Rastogi (2007) uzyskali w swych analizach odmienne wyniki. W badaniu przeprowadzonym wśród indyjskich nastolatków ustalili, że dziewczęta wykazywały wyższe poczucie sensu życia niż chłopcy. Różnice w tej kwestii mogą wynikać z faktu, że cytowani autorzy zastosowali inne narzędzie badawcze: 57-itemowy, siedmioczynnikowy Personal Meaning Profile (PMP) autorstwa Wonga (1998). Jest to rozbudowana skala, w skład której wchodzą m.in. takie wymiary, jak: osiągnięcia, relacje, religia, samotranscendencja, samoakceptacja, intymność, uczciwe traktowanie lub postrzegana sprawiedliwość. W przytoczonym badaniu wzięła także udział nieporównywalnie mniejsza próba nastolatków - 104 osoby. Pewne wyjaśnienie mogą tu także stanowić różnice kulturowe. Główną rozbieżnością wydaje się fakt, że w Indiach dziewczęta są często narażone na wykluczenie zawodowe i społeczne. Nierzadko więc muszą walczyć o najbardziej fundamentalne ludzkie prawa, co może prowadzić do uznawania egzystencji oraz każdego z jej przejawów za ogromną wartość - a to z kolei również może rzutować na wyższy poziom poczucia sensu życia.

Odpowiadając na pytanie: „Jak często polscy gimnazjaliści wchodzą w rolę ofiary lub sprawcy przemocy rówieśniczej oraz w jakim stopniu wiek i płeć różnicują te zachowania?", stwierdzono, że spośród 4085 gimnazjalistów co najmniej raz w ciągu ostatnich 2 miesięcy mniej więcej co 4 . (26,8\%) był sprawcą, a 29,8\% - ofiarą przemocy rówieśniczej. 
of peer violence. The boys were both perpetrators and victims significantly more frequently than the girls $(p<0.001)$. The findings are consistent with the results reported by Baldry (2003) in a cross-sectional study with a sample of 1,059 Italian elementary and middle school pupils. Almost half of all boys and girls reported various forms of bullying and victimisation in the previous 3 months, with boys more involved than girls in bullying others. Similar results were also obtained by Rigby and Slee (1991) in their earlier studies conducted among 685 Australian children and 32 teachers. The authors reported that approximately 1 child in 10 was subjected to peer group bullying. Boys reported being bullied more often than girls, who tended to be more supportive of victims of bullying.

With respect to the second part of the question, it was shown that boys significantly more often than girls were both perpetrators and victims of peer violence. During the preceding 2 months every $3^{\text {rd }}$ boy and every $4^{\text {th }}$ girl were perpetrators of peer violence at least once. Fifteen-year-old pupils experienced violence from their peers significantly less frequently than 13-year-olds, and even less frequently compared to 14-year-old pupils. Almost $70 \%$ of the pupils attending middle school grade 1, a similar percentage of grade 2 pupils and close to $75 \%$ of 15 -year-old pupils did not experience bullying from their peers. Similar findings were reported by Björkqvist et al. (1992) who also demonstrated genderbased differences in aggressive behaviours. The researchers conducted a series of studies among schoolchildren divided into three age cohorts: 8-year-olds $(n=85), 11$-yearolds $(n=167)$ and 15 -year-olds $(n=127)$. Different types of aggressive behaviours were measured using peer nomination techniques supported by self-ratings. Even though the studies are not questionnaire-based but qualitative in design, and despite the fact that in our study we did not differentiate between the forms of violence used, we decided to include the findings in the discussion to complement the analyses. Results obtained in a cohort of 11-year-old children were previously presented by Lagerspetz et al. (1988), however, the authors compared them additionally with other age groups. The main finding was that the girls in the two older cohorts made greater use of indirect means of aggression, whereas the boys tended to employ direct means. Research suggests that the distinction between direct and indirect aggression strategies gives a more accurate picture of the problem. Similar results to ours were obtained previously by Yang et al. (2006). The authors investigated the prevalence and correlates of bullying and victimisation behaviours (indicating assumption of the role of victim) in boys and girls at South Korean primary schools. The cross-sectional survey-based study was conducted in 1,344 primary school (grade 4) children who completed a questionnaire on self-reported bullying and victimisation behaviours, depression, anxiety, body image, coping strategies, and selfesteem as well as the self-report Strengths and Difficulties Questionnaire. The study also involved the pupils' parents.
Chłopcy istotnie częściej niż dziewczęta byli zarówno sprawcami, jak i ofiarami $(p<0,001)$. Uzyskane wyniki korespondują z wynikami badań Baldry (2003), która przeprowadziła przekrojowe badanie $\mathrm{z}$ udziałem 1059 włoskich uczniów szkół podstawowych i gimnazjalnych. Stwierdziła, że niemal połowa wszystkich chłopców i dziewcząt zgłosiła różne formy nękania i wiktymizacji w ciągu ostatnich 3 miesięcy, a chłopcy byli bardziej zaangażowani w prześladowanie innych niż dziewczęta. Podobne wyniki uzyskali również Rigby i Slee (1991) w swoich wcześniejszych badaniach, przeprowadzonych wśród 685 australijskich dzieci oraz 32 nauczycieli. Autorzy ci wykazali, że około 1 na 10 dzieci było obiektem przemocy rówieśniczej. Chłopcy raportują o byciu nękanym częściej niż dziewczęta, które z kolei chętniej wspierają ofiary.

W odniesieniu do drugiej części pytania okazało się, że chłopcy istotnie częściej niż dziewczęta byli zarówno sprawcami, jak i ofiarami przemocy rówieśniczej. W ciągu ostatnich 2 miesięcy sprawcami przemocy rówieśniczej co najmniej raz byli co 3. chłopiec i co 4. dziewczynka. Uczniowie 15-letni istotnie rzadziej doznawali przemocy ze strony rówieśników niż 13-letni, a jeszcze rzadziej - w porównaniu z uczniami 14-letnimi. Prawie 70\% uczęszczających do I klasy gimnazjum i podobny odsetek uczniów klasy II oraz blisko 75\% uczniów 15-letnich nie doznało nękania ze strony rówieśników. Podobne wyniki badań uzyskali Björkqvist i wsp. (1992), którzy wykazali różnice płci w odniesieniu do zachowań agresywnych. Przeprowadzili oni serię badań dzieci w wieku szkolnym w różnych grupach wiekowych: 8-latków $(n=85)$, 11-latków $(n=167)$ i 15-latków $(n=127)$. Różne typy zachowań agresywnych mierzono za pomocą technik nominacji rówieśniczych, wspartych ocenami własnymi. Chociaż nie są to badania kwestionariuszowe, lecz jakościowe oraz pomimo że w naszym badaniu nie różnicowaliśmy form stosowanej przemocy, ich wyniki zdecydowano się włączyć do niniejszej dyskusji jako uzupełnienie analiz. Wyniki z 11-letniej kohorty zostały wcześniej przedstawione przez Lagerspetz i wsp. (1988), ale autorzy porównali je dodatkowo z pozostałymi grupami wiekowymi. Głównym odkryciem analiz był fakt, że dziewczęta z dwóch starszych kohort wykorzystują pośrednie środki agresji, podczas gdy chłopcy zazwyczaj stosują bezpośrednie formy. Badania sugerują, że rozróżnienie między bezpośrednimi a pośrednimi strategiami agresji pozwala uzyskać dokładniejszy obraz tego problemu. Również podobne wyniki do uzyskanych przez nas dostarczyli wcześniej Yang i wsp. (2006). Ich celem było zbadanie występowania i korelacji zachowań związanych z przemocą i wiktymizacją (zachowania wskazujące na przyjęcie roli ofiary) u chłopców i dziewcząt w południowokoreańskich szkołach podstawowych. W przekrojowym badaniu ankietowym na temat zgłaszania przypadków przemocy i zachowań wiktymizacyjnych, depresji, lęku, obrazu własnego ciała, strategii radzenia sobie i samooceny, a także autorefleksji wzięło udział 1344 uczniów IV klasy szkół podstawowych. W powyższym badaniu uczestniczyli również rodzice uczniów. 
both roles was $12.0 \%, 5.3 \%$, and $7.2 \%$, respectively. The boys took on the roles of both victims and bullies much more frequently. Multivariate analyses showed that bullying and victimisation behaviours were associated with gender, greater than average height, more severe depression, higher sense of anxiety, lower self-esteem, and total difficulties in coping with problems. The authors concluded that bullying was common among South Korean primary school pupils, and bullying and victimisation behaviours were associated with a variety of emotional, behavioural, and social problems (Yang et al., 2006).

The third question used in our study was related to the hypothesised link between taking on the role of perpetrator or victim of violence and the level of sense of meaning in life. Based on answers, a statistically significant correlation was found between being the perpetrator or victim of violence and the level of sense of meaning in life $(p \leq 0.001)$. More than half of middle school pupils with high levels of sense of meaning in life never experienced violence from their peers, and 75\% were never perpetrators. Similar findings were reported by Frisén and Bjarnelind (2010) based on the results of a questionnaire survey conducted among 758 Swedish teenagers. According to their findings, approximately $15 \%$ of Swedish adolescents are involved in bullying either as bullies or victims.

Due to the lack of studies on the relationship between peer violence and the sense of meaning in life, it was decided to expand the analyses by incorporating studies reporting indirectly on the quality of life of teenagers, the assumption being that the quality of life also includes the sense of meaning in life is an essential component. Frisén and Bjarnelind (2010) found that adolescents who were victims of violence reported less energy and vitality, experienced limitations in physical activity, and assessed their mental state as worse than persons who did not experience any harassment. In their earlier studies, Wilkins-Shurmer et al. (2003) also demonstrated a relationship between violence and the quality of life, for example mental health and self-esteem. Stein et al. (2007) studied a group of 1,451 boys. On the basis of a series of questions on bullying and victimisation, the authors classified the boys as bullies, victims, bully-victims, and neutral. The victims only marginally reported better psychological health than the bullies. What this shows is that both roles, i.e. experiencing and perpetrating violence, are associated with negative consequences for mental health, particularly in young people whose emotions are not yet fully mature.

\section{CONCLUSIONS}

The reported study is innovative in that it correlated the sense of meaning in life with problems relating to peer violence. The relationship between the two aspects had not been previously explored in studies of this type. The findings highlight that the sense of meaning in life is an important construct, and it has a function of protecting
Częstość występowania sprawców, ofiar i osób wchodzących w obydwie role wynosiła odpowiednio 12,0\%, 5,3\% i 7,2\%. Chłopcy znacznie częściej byli zarówno prześladowanymi, jak i prześladowcami. W analizach wieloczynnikowych zachowania związane ze znęcaniem się i wiktymizacją wykazywały zależność od płci, wzrostu większego niż przeciętny, bardziej nasilonej depresji, wyższego poczucia lęku, niższej samooceny i całkowitych trudności w radzeniu sobie z problemami. Autorzy wykazali, że zastraszanie jest powszechne wśród południowokoreańskich uczniów szkół podstawowych oraz że przemoc rówieśnicza i zachowania związane $\mathrm{z}$ wiktymizacją wiążą się $\mathrm{z}$ różnymi problemami emocjonalnymi, behawioralnymi i społecznymi (Yang et al., 2006). Nasze trzecie pytanie badawcze dotyczyło związku wchodzenia $\mathrm{w}$ rolę sprawcy lub ofiary przemocy $\mathrm{z}$ poziomem poczucia sensu życia. Odpowiadając na nie, stwierdzono istotną statystycznie korelację między byciem sprawcą lub ofiarą przemocy a poziomem poczucia sensu życia ( $p \leq 0,001)$. Ponad połowa gimnazjalistów $\mathrm{z}$ wysokim poziomem poczucia sensu życia nie doświadczyła przemocy ze strony rówieśników, a 75\% nigdy nie było w roli sprawcy. Podobne wyniki uzyskali Frisén i Bjarnelind (2010), którzy poddali badaniu ankietowemu 758 szwedzkich nastolatków. Według uzyskanych przez nich danych około $15 \%$ szwedzkich dzieci wchodzi w rolę sprawców lub ofiar przemocy.

Z uwagi na fakt, że brakuje badań dotyczących związku przemocy rówieśniczej z poczuciem sensu życia, zdecydowano się na włączenie do analiz prac, które donoszą pośrednio o jakości życia nastolatków - jako że jej istotną składową jest również poczucie sensu życia. Frisén i Bjarnelind (2010) podają, że młodzież, która była w roli ofiary przemocy, wskazuje na brak energii i żywotności, doświadczanie ograniczeń w aktywności fizycznej oraz ocenia swój stan psychiczny jako gorszy niż osoby, które nie doświadczyły nękania. We wcześniejszych badaniach Wilkins-Shurmer i wsp. (2003) również wykazali związek między przemocą a jakością życia, na przykład zdrowiem psychicznym i poczuciem własnej wartości. Stein i wsp. (2007) przebadali 1451 chłopców. Na podstawie odpowiedzi na serię pytań o znęcanie się i wiktymizację prześladowanych autorzy ci zaklasyfikowali ankietowanych do czterech różnych grup: sprawców, ofiar, sprawców i ofiar oraz osób neutralnych. Ofiary przemocy rówieśniczej jedynie w marginalnym stopniu zgłaszały lepszy stan zdrowia psychicznego niż sprawcy. Wynika z tego, że zarówno doznawanie, jak i stosowanie przemocy niesie ze sobą negatywne konsekwencje dla zdrowia psychicznego, zwłaszcza w przypadku młodego człowieka, którego emocje są jeszcze nie w pełni dojrzałe.

\section{WNIOSKI}

Przedstawiona praca jest nowatorska, gdyż w swych analizach łączy poczucie sensu życia z problemami przemocy rówieśniczej; związek ten nie był dotychczas uwzględniany w tego typu badaniach. Zestawienie to pozwala na dostrzeżenie znaczenia ważnego konstruktu, jakim jest poczucie 
adolescents from entering into the roles of victim or perpetrator of violence. It would be worthwhile to conduct studies of this type in adults in order to establish whether the sense of meaning in life also serves as a factor protecting adults from engaging in workplace harassment behaviours as victims and perpetrators.

A limitation of this study is the application of abbreviated scales of the available research tools. However, long-term experience in studying health behaviours of Polish children and adolescents shows that the use of full scales often results in fatigue and a drop in the level of interest, ultimately leading to reluctance to complete the questionnaire to the end. However, short tools aimed at obtaining replies to the most important questions bring the desired outcomes (Mazur, 2015). Another limitation of this study is related to the age of the studied adolescents. The age differences of one year and two years between the pupils are not sufficiently large to demonstrate differences between the analysed dimensions in a satisfactory manner. A wider age range, for example from the ages of 11-12 years until approximately 19 years (i.e. secondary school graduation), could reveal a greater degree of variation depending on the level of education. Further research into the sense of meaning in life among school-aged adolescents and the search for its determinants may contribute to determining the most important predictors of this extremely important construct representing a protective factor and related to mental health (Cohen and Cairns, 2012; Halama and Dědová, 2007; Pan et al., 2008a, 2008b).

A potential practical implication of the analyses may be the implementation of programmes aimed at highlighting universal and non-material values on which young people could rely. Another important step would be to offer pupils relaxation classes and activities aimed at improving their interpersonal communication skills. They would be helpful in eliminating the problem of peer violence, clarifying adolescents' life goals, and determining the development path leading to their achievement.

Based on the results of the analyses above, it can be concluded that a high level of sense of meaning in life is a factor protecting middle school pupils against taking on the roles of both the victim and perpetrator of peer violence. In further in-depth studies it would be worthwhile to employ the PiL scale (also in its abbreviated form) as an important tool, and propose a clear distinction between known forms of peer violence. In this way, it would be possible to identify its dominant manifestations broken down by age group and gender. Another recommended measure would be to include the criterion of place of residence (village, smaller town, city) on account of specific aspects associated with different living environments.

\section{Conflict of interest}

The authors do not declare any financial or personal links with other persons or organisations that might adversely affect the content of the sensu życia, oraz jego funkcji chroniącej przed przyjmowaniem przez młodzież roli ofiary lub sprawcy przemocy. Warto przeprowadzić tego typu badania wśród osób dorosłych i sprawdzić, czy poczucie sensu życia jest również czynnikiem chroniącym przed doznawaniem i stosowaniem zachowań przemocowych w miejscu pracy.

Ograniczeniem niniejszego badania jest użycie skróconych skal narzędzi badawczych, jednak wieloletnia praktyka badań nad zachowaniami zdrowotnymi dzieci i młodzieży w Polsce pokazuje, że użycie pełnych skal często skutkuje znużeniem oraz spadkiem zainteresowania, co przekłada się na niechęć do wypełnienia kwestionariusza do końca. Pożądane rezultaty daje użycie krótkich narzędzi, ukierunkowanych na poznanie odpowiedzi na najważniejsze pytania (Mazur, 2015). Drugie ograniczenie wiąże się z wiekiem badanej młodzieży. Różnica wieku między uczniami wynosząca rok i dwa lata nie jest zbyt duża, aby w satysfakcjonujący sposób wykazać różnice między analizowanymi wymiarami. Szerszy przedział wiekowy - np. od 11.-12. do około 19. roku życia (czasu ukończenia szkoły ponadpodstawowej) - mógłby zobrazować większe zróżnicowanie ze względu na poziom edukacji. Dalsze badania nad poczuciem sensu życia wśród młodzieży szkolnej oraz poszukiwanie jego determinantów mogą pomóc w ustaleniu najistotniejszych predyktorów tego niezwykle ważnego konstruktu, stanowiącego czynnik chroniący oraz odnoszący się do zdrowia psychicznego (Cohen i Cairns, 2012; Halama i Dědová, 2007; Pan et al., 2008a, 2008b).

Implikacjami praktycznymi powyższych analiz może być wdrażanie programów kładących nacisk na eksponowanie wartości uniwersalnych i niematerialnych, do których młodzież mogłaby się odwoływać. Istotnym krokiem byłoby także zaproponowanie w szkołach zajęć relaksacyjnych i wzmacniających umiejętności komunikacji interpersonalnej. Byłyby one pomocne w eliminowaniu problemu przemocy rówieśniczej oraz sprecyzowaniu celów życiowych młodzieży, a także w wyznaczaniu ścieżki rozwoju prowadzącej do ich osiągnięcia.

Biorąc pod uwagę powyższe analizy, można stwierdzić, że wysoki poziom sensu życia jest czynnikiem chroniącym młodzież gimnazjalną przed wchodzeniem w rolę zarówno ofiary, jak i sprawcy przemocy rówieśniczej. W kolejnych pogłębionych badaniach warto uwzględniać skalę PIL (także w skróconej formie) - jako ważne narzędzie - oraz zaproponować wyraźne rozróżnienie znanych form przemocy rówieśniczej, co pozwoliłoby na poznanie jej dominujących przejawów $\mathrm{w}$ różnych grupach wiekowych oraz $\mathrm{z}$ podziałem na płeć badanej młodzieży. Należałoby również wprowadzić kryterium miejsca zamieszkania (wieś, mniejsze miejscowości oraz miasto) - z uwagi na odmienną specyfikę funkcjonowania różnych środowisk.

\section{Konflikt interesów}

Autorki nie zgłaszają żadnych finansowych ani osobistych powiazań $z$ innymi osobami lub organizacjami, które moglyby negatywnie wplynać na treść publikacji oraz rościć sobie prawo do tej publikacji. 


\section{References / Piśmiennictwo}

Baldry AC: Bullying in schools and exposure to domestic violence. Child Abuse Negl 2003; 27: 713-732.

Baumeister RF: Meanings of Life. Guilford Press, New York 1991.

Baumeister RF: The self. In: Gilbert DT, Fiske ST, Lindzey G (eds.): The Handbook of Social Psychology. $4^{\text {th }}$ ed., Vil. 1, McGraw-Hill, New York, NY 1998: 680-740.

Baumeister RF, Vohs KD: The pursuit of meaningfulness in life. In: Snyder CR, Lopez SJ (eds.): Handbook of Positive Psychology. Oxford University Press, New York, NY 2002: 608-618.

Björkqvist K, Lagerspetz KMJ, Kaukiainen A: Do girls manipulate and boys fight? Developmental trends in regard to direct and indirect aggression. Aggress Behav 1992; 18: 117-127.

Brassai L, Piko BF, Steger MF: Meaning in life: is it a protective factor for adolescents' psychological health? Int J Behav Med 2011; 18: 44-51.

Chalamandaris AG, Piette D: School-based anti-bullying interventions: systematic review of the methodology to assess their effectiveness. Aggress Violent Behav 2015; 24: 131-174.

Cohen K, Cairns D: Is searching for meaning in life associated with reduced subjective well-being? Confirmation and possible moderators. J Happiness Stud 2012; 13: 313-331.

Crumbaugh JC, Maholick LT: An experimental study in existentialism: the psychometric approach to Frankl's concept of noogenic neurosis J Clin Psychol 1964; 20: 200-207.

Elgar FJ, Craig W, Boyce W et al.: Income inequality and school bullying: multilevel study of adolescents in 37 countries. J Adolesc Health 2009; 45: 351-359.

Emmons RA: Motives and goals. In: Hogan R, Johnson J, Briggs S (eds.): Handbook of Personality Psychology. Academic Press, San Diego, CA 1997: 485-512.

Fekkes M, Pijpers FI, Verloove-Vanhorick SP: Bullying: who does what, when and where? Involvement of children, teachers and parents in bullying behavior. Health Educ Res 2005; 20: 81-91.

Frankl VE: [Logos and existence in psychotherapy]. Am J Psychother 1953; 7: 8-15.

Frankl VE: Man’s Search for Meaning. Pocket, New York 1976 [Original work published 1959].

Frisén A, Bjarnelind S: Health-related quality of life and bullying in adolescence. Acta Paediatr 2010; 99: 597-603.

Gini G, Pozzoli T: Bullied children and psychosomatic problems: a meta-analysis. Pediatrics 2013; 132: 720-729.

Graham S, Juvonen J: A social cognitive perspective on peer aggression and victimization. In: Vasta R (ed.): Annals of Child Development Vol. 13, Jessica Kingsley Publishers, London 1998: 23-70.

Halama P, Dědová M: Meaning in life and hope as predictors of positive mental health: do they explain residual variance not predicted by personality traits? Stud Psychol (Bratisl) 2007; 49: 191-200.

Harel-Fisch Y, Walsh SD, Fogel-Grinvald H et al.; Members of the HBSC Violence and Injury Prevention Focus Group: Negative school perceptions and involvement in school bullying: a universal relationship across 40 countries. J Adolesc 2011; 34: 639-652.

Janssen I, Craig WM, Boyce WF et al.: Associations between overweight and obesity with bullying behaviors in school-aged children. Pediatrics 2004; 113: 1187-1194.

Jiménez-Barbero JA, Ruiz-Hernández JA, Llor-Zaragoza L et al.: Effectiveness of anti-bullying school programs: a meta-analysis. Child Youth Serv Rev 2016; 61: 165-175.

Kaltiala-Heino R, Rimpelä M, Rantanen P et al.: Bullying at school - an indicator of adolescents at risk for mental disorders. J Adolesc 2000; 23: 661-674.

Kumpulainen K, Räsänen E, Henttonen I et al.: Bullying and psychiatric symptoms among elementary school-age children. Child Abuse Negl 1998; 22: 705-717.

Lagerspetz KMJ, Björkqvist K, Peltonen T: Is indirect aggression typical of females? Gender differences in aggressiveness in 11- to 12-yearold children. Aggress Behav 1988; 14: 403-414.

Mazur J (ed.): Zdrowie i zachowania zdrowotne młodzieży szkolnej w Polsce na tle wybranych uwarunkowań socjodemograficznych. Wyniki badań HBSC 2014. Instytut Matki i Dziecka, Warszawa 2015.

Mazur J, Małkowska-Szkutnik A (eds.): Wyniki badań HBSC 2010. Raport techniczny. Instytut Matki i Dziecka, Warszawa 2011: 152-157.

Mazur J, Tabak I, Zawadzka D: Determinants of bullying at school depending on the type of community: ecological analysis of secondary schools in Poland. School Ment Health 2017; 9: 132-142.
Molcho M, Craig W, Due P et al.; HBSC Bullying Writing Group: Crossnational time trends in bullying behaviour 1994-2006: findings from Europe and North America. Int J Public Health 2009; 54 Suppl 2: 225-234.

Olweus D: Aggression in the Schools: Bullies and Whipping Boys. Hemisphere, Washington, DC 1978.

Olweus D: Bullying at school. Long-term outcomes for the victims and an effective school-based intervention program. In: Huesmann LR (ed.): Aggressive Behavior: Current Perspectives. The Plenum Series in Social/Clinical Psychology. Springer, Boston, MA 1994: 97-130.

Olweus D: Bullying at School: What we Know and What We Can Do. Blackwell Publishing, Oxford 1993a.

Olweus D: Victimization by peers: antecedents and long-term outcomes. In: Rubin KH, Asendorpf JB (eds.): Social Withdrawal, Inhibition, and Shyness in Childhood. Lawrence Erlbaum Associates, Inc., Hillsdale, NJ 1993b: 315-341.

Pan JY, Wong DFK, Chan CLW et al.: Meaning of life as a protective factor of positive affect in acculturation: a resilience framework and a cross-cultural comparison. Int J Intercult Relat 2008a; 32: 505-514.

Pan JY, Wong DFK, Joubert L et al.: The protective function of meaning of life on life satisfaction among Chinese students in Australia and Hong Kong: a cross-cultural comparative study. J Am Coll Health 2008b; 57: 221-231

Park-Higgerson HK, Perumean-Chaney SE, Bartolucci AA et al.: The evaluation of school-based violence prevention programs: a metaanalysis. J Sch Health 2008; 78: 465-479.

Rathi N, Rastogi R: Meaning in life and psychological well-being in preadolescents and adolescents. J Indian Acad Appl Psychol 2007; 33: 31-38.

Rigby K: Consequences of bullying in schools. Can J Psychiatry 2003; 48: 583-590.

Rigby K, Slee PT: Bullying among Australian school children: reported behavior and attitudes toward victims. J Soc Psychol 1991; 131: 615-627.

Selkie EM, Fales JL, Moreno MA: Cyberbullying prevalence among US middle and high school-aged adolescents: a systematic review and quality assessment. J Adolesc Health 2016; 58: 125-133.

Stein JA, Dukes RL, Warren JI: Adolescent male bullies, victims, and bully-victims: a comparison of psychosocial and behavioral characteristics. J Pediatr Psychol 2007; 32: 273-282.

Ttofi MM, Farrington DP: Effectiveness of school-based programs to reduce bullying: a systematic and meta-analytic review. J Exp Criminol 2011; 7: 27-56.

Turner JC: Social comparison and social identity: some prospects for intergroup behaviour. Eur J Soc Psychol 1975; 5: 5-34.

Vaillancourt T, Hymel S, McDougall P: The biological underpinnings of peer victimization: understanding why and how the effects of bullying can last a lifetime. Theory Pract 2013; 52: 241-248.

Wilkins-Shurmer A, O'Callaghan MJ, Najman JM et al.: Association of bullying with adolescent health-related quality of life. J Paediatr Child Health 2003; 39: 436-441.

Wong PTP: Implicit theories of meaningful life and the development of the Personal Meaning Profile. In: Wong PTP, Fry PS (eds.): The Human Quest for Meaning: A Handbook of Psychological Research and Clinical Applications. Lawrence Erlbaum Associates, Inc., Mahwah, NJ 1998: 111-140.

Wood JV: Theory and research concerning social comparisons of personal attributes. Psychol Bull 1989; 106: 231-248.

Yang SJ, Kim JM, Kim SW et al.: Bullying and victimization behaviors in boys and girls at South Korean primary schools. J Am Acad Child Adolesc Psychiatry 2006; 45: 69-77.

Zawadzka D, Korzycka M: Poczucie sensu życia a subiektywna witalność i status socjoekonomiczny gimnazjalistów. Psychol Wych 2018; 13: 70-82.

Zawadzka D, Stalmach M, Oblacińska A et al.: Związek poczucia sensu życia z zadowoleniem z życia, występowaniem dolegliwości subiektywnych oraz statusem ekonomicznym rodziny w populacji uczniów gimnazjum. Dev Period Med 2017; 21: 60-68

Zawadzka D, Stalmach M, Tabak I: Poczucie sensu życia a samoocena zdrowia i osiągnięcia szkolne uczniów w wieku 13-17 lat. Pediatr Pol 2016; 91 : 566-573.

Życińska J, Januszek M: Test Sensu Życia (Purpose in Life Test, PIL) J.C. Crumbaugha i L.T. Maholicka: analiza psychometryczna. Czas Psychol 2011; 17: 133-142. 